\title{
GARAP MUSIKAL GENDING DALAM FILM SETAN JAWA
}

\author{
Hannova Aji Finarno \\ Alumni Jurusan Etnomusikologi Fakultas Seni Pertunjukan \\ Institut Seni Indonesia (ISI) Surakarta \\ Email: Hanova-_ajik@yahoo.com \\ Santosa \\ Dosen Jurusan Etnomusikolgi Fakultas Seni Pertunjukan \\ Institut Seni Indonesia (ISI) Surakarta \\ Email: santosa.isisolo@gmail.com
}

\begin{abstract}
Abstrak
Film Setan Jawa merupakan sebuah film bisu hitam putih yang dalam pemutaran filmnya diiringi oleh gamelan secara langung, Pertunjukan Film Setan Jawa mengangkat kisah mitologi Jawa yang diangkat dari kisah kisah nyata dari berbagai daerah. musik gamelan yang mengiringi film Setan Jawa komposer Rahayu Supanggah, dengan garap musik gamelanya yang menjiwai tiap adegan pada film Setan Jawa. Pendekatan yang digunakan adalah pendekatan musikologi. Penelitian ini tentang garap musikal gending, maka konsep yang dipakai adalah konsep-konsep musikologi karawitan Jawa. Konsep ini selain mengkaji tentang garap gending juga membahas konsep pathet, irama, bentuk dan struktur gending. Hasil penelitian ini ditemukan bahwa pada pementasan film Setan Jawa, gending-gending yang digunakan dalam mengiringi setiap adegan memiliki sajian garap yang berbeda dari penyajian adegan satu dengan yang lainnya. Setiap penyajian yang berbeda-beda tersebut mengalami perbedaan serta perubahan dalam sajian tafsir garapnya. Pemilihan gending dalam garap musikal film Setan Jawa, Supanggah menggunakan gending-gending lama. Hal ini selain digunakan untuk menghidupkan suasana film, pemilihan gending juga disesuaikan dengan konteks dalam adegan cerita.
\end{abstract}

Kata kunci: Setan Jawa, Karawitan, Garap.

\begin{abstract}
The "Setan Jawa" movie is a silent black and white move that in its screenings is accompanied by a direct gamelan orchestra. "Setan Jawa" movie raised a Javanese mythological story based on true stories from various regions. The gamelan music that accompanies the movie composed by Rahayu Supanggah, with the gamelan music that animates each scene in the movie. The approach that is used is the musicology approach. This research is about working on the movie's musical tunes (gending), the concepts used are Javanese musical concepts. Apart from studying the concept of gending, this concept also discusses the concept of pathet, rhythm, the shape and structure of gending. The results of this research found that in the staging of "Setan Jawa" movie, the music used to accompany each of the scene has a different presentation from the presentation of one scene to another. Each of these different presentations experiences differences as well as changes in the interpretation of the gending. Supanggah selected old gending for the musical work of the "Setan Jawa" movie. Apart from it, the selection of gending used to liven up the atmosphere of the film as well as adjusting it to the context in the story scene.
\end{abstract}

Keywords: Setan Jawa, Karawitan, Garap. 


\section{Pengantar}

Indonesia terdapat beragam suku, adat, dan budaya. Salah satu kekayaan budaya yang dimiliki masyarakat adalah musik daerah yang lahir dan berkembang. Karawitan merupakan salah satu budaya musik milik Indonesia, khususnya masyarakat Jawa. Mayoritas kesenian karawitan Jawa menggunakan instrumen gamelan. Di kalangan masyarakat indonesia, terutama lingkungan para praktisi, istilah gamelan biasa digunakan (hanya) untuk menyebut sejumlah atau seperangkat ricikan atau alat musik atau instrumen musik, dengan jenis dan jumlah tertentu yang memenuhi syarat untuk memenuhi kebutuhan dan/atau keperluan tertentu walau kemudian perkembanganya di luar Indonesia gamelan juga digunakan untuk menyebut dunia musikbukan sekedar terbatas pada alat-yang menggunakan alat gamelan atau sejenis. (Supanggah, 2002: 13).

Dalam sepak terjang perjalanan musik gamelan terdapat perkembangan yang terjadi pada dunia seni karawitan. Hal ini menggambarkan bahwa seni karawitan merupakan suatu produk kebudayaan yang selalu ingin berkembang, menyesuaikan dengan kondisi jaman atau perubahan kehidupan masyarakat. Sesuai dengan kodratnya, bahwa seni karawitan sebagaimana cabang seni pertunjukan tradisi lainnya dikategorikan dalam jenis seni komunal, yaitu seni yang lahir dari, oleh, dan untuk masyarakat. Keberadaan dan perkembangannya tergantung pada kondisi masyarakat. Seiring perkembangan seni karawitan bukan hanya penambahan jenisjenis gamelan saja, melainkan fungsi seni karawitanpun mengalami perkembangan. Menurut Rahayu Supanggah, gamelan dibagi menjadi dua fungsi yaitu (1) mandiri, (2) digunakan untuk keperluan lain, tari, wayang, teater dan/atau upacara. Saat ini perkembangan karawitan Jawa yang menggunakan intrumen gamelan sering digunakan untuk mengiringi film, baik sebagai ilustrasi musik film yang direkam terlebih dahulu, atau iringan langsung pada film bisu.
Ilustrasi karawitan Jawa yang dimainkan dalam film bisu sebenarnya secara fungsi sama persis dengan fungsi karawitan untuk mengiringi pertunjukan wayang. Dalam film Setan Jawa yang disutradarai oleh Garin Nugroho menggunakan musik karawitan sebagai ilustrasi yang dimainkan secara langsung. Menurut Garin ide penggunaan musik karawitan Jawa dalam film Setan Jawa terinspirasi oleh pertunjukan wayang kulit. Dalam film tersebut terdapat layar hitam putih sebagai media untuk proyeksi film.

Kehadiran karawitan dalam pemutaran Film Setan Jawa cukup menarik, pasalnya dimainkan secara langsung untuk mengiringi jalanya film. Film ini terbagi atas bebeapa adegan. Pada setiap adegan iringan musik berbeda-beda, selain untuk membangun suasana film bisu ini ternyata musik gamelan yang mengiringi pemutaran film ini menurut sang komposer juga memiliki garap gending tersendiri pada setiap adeganya.

Gending memiliki peranan yang sangat penting untuk mendukung penyajian karawitan Jawa dalam berbagai fungsinya salah satunya dalam mengiringi pemutaran film Setan. Pada pementasan film Setan Jawa , gending-gending yang digunakan dalam mengiringi setiap adegan memiliki sajian garap yang berbeda dari penyajian adegan satu dengan yang lainnya. Setiap penyajian yang berbeda-beda tersebut nantinya akan mengalami perbedaan serta perubahan dalam sajian tafsir garapnya.

Pemilihan gendhing dalam garap musikal film Setan Jawa oleh rahayu supanggah sebagian menggunakan gendhinggending lama. Hal ini selain digunakan untuk menghidupkan suasana film tersebut juga pemilihan gending juga disesuaikan konteks dalam adegan cerita.

\section{Pembahasan}

Film Setan Jawa yang disutradarai Garin Nugroho merupakan sebuah film dalam rangka merayakan 35 tahun berkarya di industri perfilman Indonesia. Film Setan Jawa ini didukung oleh Bakti Budaya Djarum 
Foundation. Istimewanya film ini merupakan sebuah film bisu hitam putih yang diiringi dengan live musik gamelan, oleh komposer terkenal Rahayu Supanggah.

Pertunjukan Setan Jawa mengangkat kisah mitologi Jawa yang merupakan bagian dari kekayaan budaya Indonesia. Di dalam kisah-kisah mitologi daerah di Indonesia tersimpan nilai-nilai luhur serta ajaran moral yang berakar dari sejarah dan tradisi masyarakat. Mitologi mengandung kearifan lokal yang mampu membentuk pola dan perilaku masyarakat agar menghormati serta berbuat lebih baik terhadap sesuatu yang dianggap bernilai, suci, dan sakral.

Inspirasi film Setan Jawa adalah dari film hitam putih klasik bertajuk nosferatu (1992) dan metropolis (1927). Kedua film klasik ini telah berkeliling ke berbagai belahan dunia dengan diiringi langsung orkestra. Selain itu inspirasi penting pembuatan film ini adalah dari wayang kulit. Pertunjukan tradisi ini telah menjadi bagian hidup yang memprakarsai film ini, dikarenakan cara bercerita lewat sosok wayang lewat imagi bayangan. Menurut sang sutradara Garin Nugroho, sebuah dunia antara dunia realis dan dunia non realis. Dunia wayang kulit merupakan sebuah dunia imagi sendiri. Didalam dunia wayang kulit bisa menciptakan imagi warna yang kaya dalam banyangan dunia abu-abu yang tidak terbatas.

Film Setan Jawa kemudian menjadi eksplorasi bahasa sinema baru yang mengkombinasikan tradisi tutur Jawa dengan teknologi tutur baru. Film ini menjadi perwujudan dari sebuah intesitas dan sinergitas proses kreatif dengan ruang untuk imajinainasi, eksplorasi dan inovasi antara beragam seniman unggul Indonesia dengan latar seni yang beragam pula, baik sinergitas pembuat film, teater, fasion, sastra, musik, tari, hingga fisual art.

\section{Sinopsis Film Setan Jawa}

Garin menciptakan beraneka ragam karya, salah satunya film bisu hitam putih Setan Jawa. Film ini adalah kisah dan tragedi kemanusiaan dengan latar waktu awal abad ke-20. Era Kolonial ini ditandai lahirnya era industri yang menyaksikan kemiskinan yang sangat besar ditanah Jawa. Seiring dengan meluasnya kemiskinan maka bertumbuh dengan subur cara-cara mistik untuk meraih kekayaan, salah satunya pesugihan "kandhang bubrah", yaitu mencari pesugihan dengan cara diri sendiri menjadi tumbal.

Kisah dimulai lewat riwayat setan pesugihan semasa kecil. Kisah anak kecil Jawa yang mencuri uang di rumah mewah orang kaya sehingga menjadikannya ia dipenjara. Dalam penjara anak kecil itu membunuh seorang serdadu sehingga anak itu dihukum dengan sangat kejam. Kemudian mati dan menjelma menjadi setan pesugihan yang bermukim di sebuah candi.

Kisah selanjutnya menceritakan seorang pemuda yang bernamaSetyo, seorang pemuda miskin dari desa yang berdagang di pasar. Di dalam berdagangSetyo bertemu dengan Asih seorang anak dari kalangan bangsawan. Awal mula tragedi terjadi ketika lamaran Setyo ditolak keras oleh keluarga Asih. Untuk bisa mendapatkan wanita idaman hidupnya kemudianSetyo mencari pesugihan kekayaan untuk bisa melamar Asih dari golongan bangsawan. Lewat perjalanan mistik, Setyo akhirnya memilih pesugihan kandhang bubrah. Dalam waktu sekejap Setyo yang awalnya miskin kemudian mendadak menjadi kaya, sehingga lamaranya ke Asihpun akhirnya diterima. Dengan berjalannya waktu ia hidup bahagia dan membangun rumah Jawa yang sangat megah.

Dalam perjalanan hidupnnya sebagai istri, Asihpun lama kelamaan merasa janggal dengan perilaku suaminya. Perilaku keseharian yang aneh yang berusaha setiap hari berusaha memperbaiki rumahnya. Oleh karena dirasa janggal sekaligus melihat proses rumahnya setiap hari dirusak oleh utusan setan. Asih kemudian mengetahui bahwa suaminyaSetyo menggunakan pesugihan kandhang bubrah. Asih yang sangat mencintai suaminya kemudain menemui setan pesugihan. Asih meminta pengampunan agar suaminya pada saat kematianya tidak menjadi tiang penyangga rumah. 
Ternyata setan pesugihan itu justru jatuh cinta kepada Asih dan meminta tubuhnya sebagai imbalan pengampunan. Asih yang mengalami tekanan batin dan teror karena rumahnya semakin rusak parah dan sang suami mengalami sakit keras, akhirnya memutuskan untuk menjadikan tubuhnya sebagai imbalan kepada setan atas suaminya dengan berharap hukuman kepada suaminya terhapus. Unsur yang terkandung dalam Film Setan Jawa: 1) Setan, 2) Kolonialisme, 3) Dunia mistik, 4) Pesugihan, 5) Ralisme magis, 6) Sensualitas, 7) Gamelan.

\section{Istilah Karawitan dan Garap Gending}

Di Jawa, salah satu jenis bunyi bunyian yang dianggap tua dan masih bertahan hidup dan berkembang sampai sekarang adalah karawitan atau (diluar Indonesia lebih dikenal sebagai) musik gamelan. Istilah karawitan merupakan istilah yang paling baru, namun penggunaan dan pemaknaanya semakin berkembang, memiliki cakupan wilayah geografis ataupun wilayah budaya yang luas. Istilah karawitan sekarang ini sering juga digunakan untuk menyebut jenis musik lainya yang memiliki sifat, karakter, konsep, cara kerja, dan atau aturan yang mirip dengan musik karawitan Jawa. Menurut etimologi kata karawitan berasal dari kata rawit yang berarti kecil, rumit, halus. Bertolak dari pengertian itu tidak mengherankan bila karawitan kemudian dapat digunakan untuk menyebut atau mewadahi beberapa cabang seni yang memiliki karakter yang halus, kecil, umit, atau sejenisnya.

Penggunaan istilah gamelan dan karawitan sudah mulai "sama" dengan yang diberlakukan di Indonesia, terutama oleh praktisi maupun para akademisi yang berhubungan lebih jauh atau akrab dengan dunia musik gamelan, dunia karawitan. Kalangan masyarakat di Indonesia, terutama lingkungan praktisi, istilah gamelan bisa digunakan (hanya) untuk menyebut sejumlah atau perangkat ricikan atau alat musik atau instrumen musik, dengan jumlah tertentu yang sudah memenuhi syarat untuk memenuhi kebutuhan dan/ atau keperluan tertentu (walau kemudian perkembanganya di luar indonesia gamelan juga digunakan untuk menyebut dunia musik, bukan sekedar terbatas pada alat). Kebutuhan atau keperluan itu dapat berupa kebutuhan dari seorang atau sekelompok orang dalam konteks penyajian religi-sosial-budaya, atau dalam konteks penyajian seni maupun dalam konteks iringan.

Gamelan sendiri merupakan seperangkat ricikan yang sebagian besar terdiri dari alat musik pukul atau perkusi yang terbuat dari bahan utama logam(perunggu, kuningan, besi atau bahan logam lain), dilengkapi ricikan-ricikan dengan bahan kayu dan/atau kulit maupun campuran dari dua atau tiga bahan tersebut. Istilah gamel (dalam bahasa jawa) berarti memukul. Itulah kemungkinanya mengapa gamelan dapat dianggap sebagai satu perangkat musik pukul atau perkusi. Walau pada kenyataannya perangkat gamelan juga melibatkan alat alat musik non perkusi, seperti gesek (rebab), tiup (suling), juga petik (siter dan celempung), selaput kulit atau membran (kendang) kocok (rijal dalam perangkat gamelan kodok ngorek), dan sebagainya.

Penelitian kali ini lebih menekankan pada aspek-aspek yang berkait erat dengan persoalan garap musikal gending. Pendekatan yang digunakan adalah pendekatan musikologi. Karena penelitian ini tentang garap musikal gending, maka konsep yang dipakai didasarkan pada konsep-konsep musikologi karawitan Jawa. Konsep ini selain mengkaji tentang garap gending antara lain juga membahas konsep pathet, irama, bentuk dan struktur gending. Selanjutnya konsep-konsep tersebut dimanfaatkan untuk menganalisis gending sasaran. karenanya penelitian ini memakai konsep garap Rahayu Supanggah. Landasan yang digunakan untuk menjawab permasalahan yang ada di dalam penelitian ini yaitu dengan menggunakan pendekatan musikologi yang dipaparkan oleh Rahayu Supanggah.

Garap merupakan suatu istilah yang tidak hanya digunakan dalam bidang karawitan, akan tetapi juga digunakan dalam 
dunia kesenian lainnya. Di Jawa istilah garap hampir digunakan pada semua jenis kesenian, terutama pada seni pertunjukan.

Garap merupakan rangkaian kerja kreatif dari sekelompok pengrawit dalam menyajikan sebuah gending atau komposisi karawitan untuk dapat menghasilkan bunyi dengan kualitas tertentu sesuai dengan keperluan atau tujuan dari sesuatu kekaryaan/atau penyajian karawitan yang dilakukan (Supanggah, 2007:3).

Dalam bukunya jelas Supanggah menyatakan bahwa garap adalah kreativitas dalam kesenian tradisi. Jadi, garap merupakan hal yang sangat penting/atau esensial dalam dunia seni karawitan. Garap adalah sebuah sistem. Unsur-unsur pembentuk teori garap/ atau kreativitas karawitan menurut Supanggah adalah: 1). materi garap atau ajang garap, 2). penggarap, 3). sarana garap, 4). perabotgarap,5). penentugarap,dan 6). Pertimban gangarap.

Suatu pertunjukan tampak begitu jelas bahwa seorang seniman (pengrawit) merupakan salah satu aspek terpenting terhadap kualitas dari hasil sajian garap (Supanggah, 2007:26). Selain dari faktor seniman yang dijelaskan tersebut masih banyak terdapat faktor lain yang berpengaruh terhadap sajian garap. Adapun faktor lain yang mempengaruhi sajian garap gending yaitu tentang keperluan gending itu digunakan.

Pada kenyataannya gendhing Karawitan mempunyai garap yang bervariasi sesuai dengan kebebasan yang dimiliki oleh pengrawitnya. Hal ini terkait dengan kemampuan seniman (pengrawit) yang menyajikannya. Kemampuan pengrawit yang dimaksud adalah bagaimana seorang pengrawit di dalam menyajikan garap ricikan harus melalui proses menafsir garap gendingnya. Seperti yang telah dikemukakan oleh Rahayu Supanggah bahwa untuk menjadi sebuah sajian gending,. Dengan demikian kualitas sajian suatu gending sangat tergantung pada kemampuan, pengalaman dan tafsir pada senimannya.
Untuk penguasaan garap tersebut seorang pengrawit harus menguasai tafsir pathet, irama, cengkok, wiletan, volume, laya, garap ensambel, sindenan dan garap ricikan. Berdasarkan konsep yang dipaparkan oleh Rahayu Supanggah tersebut, dapat diketahui bahwa kemampuan seorang seniman dalam menafsir sebuah balungan gending menjadi unsur pokok dalam suatu hasil penyajian gending. Untuk dapat menyajikanya dalam konteks iringan film juga memilih gending yang cocok seorang pengrawit memiliki skil tersebut. Dengan demikian, konsep ini akan digunakan untuk menganalisis garap sajian gendhing pada adegan film Setan Jawa.

\section{Garap Musik Film Setan Jawa}

Film Setan Jawa dalam pemutaran filmnya menggunakan iringan langsung gamelan orkestra. Repertoar gending yang disajikan merupakan ciptaan dari komposer Rahayu Supanggah dengan menggunakan gending-gending yang sudah ada yang dirangkai. Proses pembuatan, musik Setan Jawa ini yamg pertama kali dibuat adalah filmnya dulu, baru dibuat dan disuaikan musiknya. "Kebetulan musik, apa ya, untuk musiknya itu sudah ada semua, tinggal nempel nempel saja." (Widodo, 08 Januari 2018).

Musik gamelan dalam film Setan Jawa terdapat dua versi kompsoisi. Yang pertama versi full gamelan, dalam versi full musik gamelan ini gending yang mengiringi adegan sudah disusun secara paten. Ke dua adalah versi gamelan dengan kolaborasi orkestra. Saat musik gamelan berkolaborasi dengan orkestra proses jalannya musik menurut Wahyu Thoyyib mengatakan:

Dadi anu nak orkestra kuwi sing dadi gamelan sik, orkestrane dhéwé mara réné prosèsé dhèwèké nonton gamelané. La dhèwèké gawé, dee ngleboni sing kira kira isoh dileboni orkestra, terus ènèk sing bagian. Enèk menèh sing bagian gamelané bener bener diam. Orkestra thok kuwi ya ènèk. Tapi ènèk sing dhèk-é nggawé komposisi dinggo mendukung gamelan ya 
ènèk. Dadi memang sing mangkat disik gamelan sing menyesuaikan orkestrané. (Toyyib, 10 Januari 2018)

Maksud dari pernyataan Thoyyib di atas adalah saat musik orkestra masuk, yang mendahului adalah tetep gamelanya. Untuk proses peciptaan musik orkestra, dengan cara sang komposer mendengarkan musik serta melihat adegan lalu sang komposer membuat komposisi yang pas untuk melanjutkan atau mengisi suara adegan. Orkestra masuk mengisi melihat dan menyelaraskan dengan adegan. Ada juga musik orkestra bertanggung jawab penuh untuk mengiringi adegan dan gamelan saat itu benar-benar diam. Ada juga komposisi orkestra yang mendukung musik gamelan. Tetapi tetap dalam keseluruhan struktur musik yang bertanggung jawab penuh dan memulai mengiringi adegan adalah musik gamelan.

Pernyataan yang sama juga dilontarkan oleh Widodo seperti berikut:

Orkestrané kuwi malah mendukung dari gamelanya itu sendiri. Itu tergantung dari sang sutradara. Tapi ada juga yang gamelan, yang tadinya musiknya tidak ada tapi terus dihilangi, digantikan dengan orkestra, itu kebutuhan, kebutuhan nggak tau ya mungkin sutradaranya. (Widodo, 8 Januari 2018).

Maksud dari pernyatan Widodo itu adalah musik orkestra yang mengiringi jalanya filem itu sebenarnya adalah untuk mendukung musik gamelan. Hal ini tentu adalah pilihan dan kemauan dari sutradara. Awalnya ada musik gamelan kemudian dipotong dan dilanjutkan iringan musik orkestra. Itu adalah kemauan dari sutradara. Jadi dalam mengiringi terdapat pembagian kapan gamelan mengiringi, dan kapan musik gamelan mengiringi terus diam dilanjutkan musik orkestra. Ada juga adegan yang hanya diiringi musik orkestara.

\section{Gending yang disajikan}

Struktur gending dalam film Setan Jawa sudah tetap atau paten. Musik yang dibuat untuk mengiringi adalah bukan sepenuhnya dari sang komposer Rahayu Supanggah. Melainkan para musisi yang lain juga bisa menentukan. Dalam pernnyataan Widodo, seorang penabuh bonang panembung mengatakan:

Kalau ketika proses Setan Jawa ini ya. film ini ya jadi kan sudah punya pemusik temen temen juga bisa menentukan. Oh iki énaké musik sing kaé, tempel. Iki énaké sing kaé, kemudian tempel. Tetapi ya persetetujuan bersama. Jadi diberi kebebasan untuk masing masing pemusik. Tapi juga persetujuan dari pak panggah sendiri ya. La kira kira iki wis penak apa durung, pak panggah mendengarkan (Widodo, 08 Januari 2018)

Jadi musisi lain juga bisa menentukan, gending yang digunakan, tetapi dengan catatan tetap harus dengan persetujuan komposer. Pembuka musik dalam film Setan Jawa versi full gamelan adalah gamelan itu sendiri, tetapi untuk kasus mengiringi film Setan Jawa, berbeda dengan konser tunggal gamelan.

Kalo kalo di karawitan kan ada istilahnya pamurba irama. Pamurba irama itu yang menentukan irama, yang mempunyai wenang adalah kendang. Terus mau menghentikan, mempercepat memperlambat itu kendang. Tetapi di musik ini ada beberapa yang ditugaskan untuk menentukan itu. Cepat lambatnya tempo, menyesuaikan adegan, kapan harus habis kapan harus mulai, itu masing masing instrumen diberi kekuasaan itu. Jadi dalam hal ini pamurba irama itu ga harus kendang. Karena disitu kendang malah minim sekali bermain seperti bonang penembung itu diberi itu. Kemudian slenthem ada peran. Vokal juga. Ada komposisinya pak panggah yang aba aba malah dari vokal. Itu terlambat atau kecepeten itu tergantung dari yang vokal. Aba aba dari vokal seperti itu. Jadi semua bisa menjadi kondaktor. Iya ketika adegan ini o kondaktornya demung, ketika adegan ini o kondaktornya bonang, bagian ini kondaktornya kendang yang bagian ini kondaktornya vokal harus nurut gitu, pembagian pembagian itu. (Widodo, 08 Januari 2018) 
Menurut Widodo Pada konser tunggal gamelan, yang berhak menuntun jalanya irama atau dalam karawitan sering disebut dengan istilah pamurba irama adalah kendang, tetapi dalam kasus film Setan Jawa ternyata semua intrumen berhak dalam memulai ataupun mengendalikan irama. Karena di dalam mengiringi musik justru instrumen kendang sedikit bermain. Dalam versi dua atau versi kolaborasi dengan musik orkestra, yang menjadi aba-aba adalah sang kondaktor musik orkestra "Ya ketika dengan orkestra kalo musik orkestra itu satu komando dengan kondaktor. Jadi ketika gamelan." Musik gamelan dalam mengiringi film bisu Setan Jawa menggunakan gending gending yang sudah ada, dan oleh Rahayu supanggah dirangkai berdasarkan ilustrasi film. Rangkaian jalanya urut urutan gending :

\section{Pocapan Intro hingga tulisan Setan Jawa Prolog}

Adegan beberapa tawanan penduduk peribumi yang ditahan oleh serdadu Belanda (terlihat dari kostum yang dipakai) dalam adegan tersebut tersebut terlihat seoarang penjaga memborgol kaki seorang anak kecil dengan menggunakan rantai yang ujungnya bola besi, anak kecil itu menjadi orang pertama dan menuju sel tahanan dengan borgol besi dikakinya. Kemudian dalam antrian terdapat beberapa pemuda yang mengantri akan diborgol.

Ricikan Bonangan Sekatèn disajikan bersama Sekar Macapat Dhandanggula Gedhongkuning, laras slendro pathet sanga

Didalam tahanan seorang anak kecil itu terlihat tersiksa, bahkan mengumpulkan tanah liat disekitarnya untuk dimakan. Sehingga mati mengenaskan.

\section{Chapter 1}

\section{Pertemuan cinta - the road of love}

$$
\text { Shynth = kethuk kenong kempul }
$$

Capter pertama ini menceritakan penduduk peribumi disuatu desa yang sedang berkerja di suatu gubuk. Didalam cerita tersebut digambarkan gubuk atau rumah itu adalah rumah seorang pemuda bernama Setyo. Disekitar rumah Setyo terdapat berbagai aktivitas, yaitu aktivitas yang dilakukan beberapa orang tersebut adalah ada yang sedang mencari, memngeringkan, memilah daun kelapa / ijuk, Pathetan terdapat juga aktivitas menganyam bambu dalam istilah Jawa disebut gedhèg (tembok dari anyaman bambu) yang nantinya akan dibuat sapu dan dijual disebuah pasar kolonial.

\section{Ketawang sinom legawi, laras pelog pathet nem}

Setelah itu berpindah ke adegan berikutnya, adegan dimana terdapat Asih, Ibu Asih, Nenek Asih. Dimana Asih yang sedan melakukan aktivitas nganyam rambut. Sedangkan ibu sih membetulkan kain jawa/jarik. Setelah itu Ibu asih menata rambut asih.dengan adegan dilayar ibu asih menari.

\section{Shynth + gembyungan gendèr}

adegan selanjutnya Setyo dan teman yang baru datang di pasar dari rumahya mulai meletakan dan menata barang jualanya, tidak lama kemudian seorang puti dan ibunya mengendarai Kereta kencana, rakyat sekitar yang melihat kedatangan Asih terlihat menyembah untuk menghormati (gending: pathetan ati, laras pelog pathet nem) Setyo melihat kedatangan asih dari jauh dan memperhatikannya karena merasa tertarik. punokawan yang ikut dalam kedatangan mendampingi Asih berkeliling dipasar. Karena pasar tersebut ramai tidak sengaja ada penjual gedek menyambar Asih sehingga tusuk kondenya jatuh tetapi asih tidak tau, melihat kejadian itu Setyo langsung mengambilnya. Setelah dijalan Rupanya asih baru sadar tusuk jatuh dan ditemukan seseorang. Dalam perjalanan asih sadar diikuti seseorang. 


\section{Gendhing Goyah}

Adegan selanjutnya adalah adeganSetyo menari dirumah menggunakan tusuk konde. Dilajutkan dalam adekan yang sama ditepat asih terlihat asih sedang dibbersihkan serpti ritual.

\section{Chapter 2}

Misteri tubuh dan cinta - miseties body and
love

Shynth + Instrumen kontemporer +vokal +gambang

Adegan pertama Setyo berjalan jongkok didalam rumah menuju tempat asih dan ibunya yang berniat mengembalikan tusuk konde. Saat tau maksud kedatangan ibu asih marah dan menusukan tusuk konde itu ke tanganSetyo asih terlihat tidak tega dan menangis, ibu menahanya. Nenek asih yang juga berada disitu menyuruh dengan gerakan untuk mengusir Setyo.

\section{Chapter 3}

pasar mistik- the mystikc market

Shynth + instrumen kontemporer + Genderan ada ada

adegan ini setyo merasa kesal dan marah saat berkerja, kemudia menggunakan sapunya sebagai topeng dan menari dengan topeng tersebut.

Adegan menimba, kemudian setyo mengguyur air dalam ember dan memakai ember kekepala dilanjutkan menari dengan kepala tertutup ember disekitar sumur rumahnya.

Disela sela aktivitas membuat sapu teman setyo terlihat membawa sesajen untuk sumur, setyo melihat hal itu dan menyampar sesajenya lalu temanya terlihat mengambil kembali sajennya. LaluSetyo terlihat mau pergi kesesuatu tempat. adegan dilayar beberapa wanita menari

\section{Grambyangan gambang grantang}

Di pasar itu terlihatSetyo merasa asing seperti di pasar mistik.Setyo jalan jalan merasa asing dan melihat setan padi musik rebana, topeng, melihat gambar pada adegan setan tua. Stelah ituSetyo dan setan melakukan ritual-ritual, ternyata itu di dunia. Tubuh aslinya sedang terbaring ditemani setan satu. Setan lain menari diatas batu, kemudianSetyo sadar dari mimpinya dan mengikuti setan satu ke suatu tempat ditemani setan setan yang lain.

\section{Lagu Kartini}

Shot relief candi. Adegan selanjutnyaa setan dan Setyo

\section{Capter 4}

\section{Hutang yang harus dibayar pada setan - indested to satan}

Adegan Setyo memahat topeng.

Melihat penyu musik Mantram. Setyo menyaruk koin dan tanah dari belakang penyu kemudian menyebarkanya perlahan di depan mukanya. Adegan Setyo menari topeng dengan melihat penyu dan mengambil koin. Selanjutnya umahnya.

\section{Tembang Salisir}

Setyo membawa koin dalam wadah dan menyebarkanya diesekitar.

\section{Chapter 5}

Jalan gaib setan, rumah selau rusak.

Gecul Punokawan, lindri, laras slendro pathet sanga.

asih dan setyo menuju rumahnya menggunakan kereta kenvcana, penjaga hormat. Adegan Setyo memberikan sesaji kesebuah cagak/ tiang. Kemudian Membuka sebuah topeng, tetapi asih terlihat bingung dan curiga . Mereka masuk kerumah. 
Adegan selanjutnya dimana asih sedang nyantai dan dihibur pelayan laki perempuan, dan ditemani puno kawan.

\section{Musik JO selingkuh}

Adegan Adegan sensual Setyo dan asih

\section{Kuntulan}

Tiba tiba scane berpindah ke Setan Jawa Adegan setan perusak dan piayakan dengan iringan rebana merusak rumah dibantu bala bantuan kepiting

\section{Shynth + humming vokal}

Asih terbangun dan melihatnya, keluar kamar berjalan dan kembali ke kamar karena ketakutan.

Adekan ibu dengan asih

Adegan asih memberi sesaji kerumahnya yg muncul setan perusak ketakutan .

AdeganSetyo menari dengan topeng mengelus tembok dengan tanah liat.

Asih berusaha mncari setan dirumahnya memegang sapu (musik rebana). Asih berdiri menangis (vokal kuntulan) Setyo merasa kesakitan ketikan kepiting dibakar gonggominan Tulungagungan.

bingung (Solo vokal = shynth +instrumen kontemporer suwuk)

\section{Chapter 6}

\section{Takdir}

Adegan Setyo menyelupkan wajahnya dan ke ember tanah liat, asih melihatnya dan tiba-tiba Setyo pergi kabur. Setyo meninggalkan topeng. Asih berusaha mencari Setyo, masuk ke ruangan menemukan kertas.

\section{Musik Mubeng, laras pelog}

Adegan baru asih dan ibunya menari dirumah ibunya yang

\section{Musik Gugat}

Adegan baru asih jalan jalan bersama punokawan

Melihat penyu di kolam wajah terlihat kaget ketakutan.

\section{Buka krucilan}

Kemudian llanjut dan beristirahat di batu. Asih beserta para punokawan tidur. Kemudian disamperin setan padi dan asih dibawanya pergi. Punokawan terbangun kaget melihat asih hilang dan berusaha mencari bingung mencari. Sirep pelungan.

Doa iki siti laras pelog pathet nem Ternyata dibawa ke suatu tempat berhasil ditemukan tetapi punokawan diusir oleh setan.

Asih turun dari candi (gending kemanak pangajabsih, laras pelog pathet nem)

Topeng dibakar siteran dan improvisasi panembung

\section{Capter 7}

\section{Persembahan diri untuk pengampunan.}

Percintaan Asih dan setan (Sekar Macapat Dhandhanggula Tlutur, laras slendro pathet sanga) Asih menancapkan tusuk konde (musik daging II) Tulisan yang saya cetak miring di atas merupakan urut-urutan jalanya gending pada setiap adegan dalam film Setan Jawa.

\section{Kesimpulan}

Gending memiliki peranan yang sangat penting untuk mendukung penyajian karawitan Jawa dalam berbagai fungsinya salah satunya dalam mengiringi pemutaran film Setan. Pada pementasan film Setan Jawa , gending-gending yang digunakan dalam mengiringi setiap adegan memiliki sajian garap yang berbeda dari penyajian adegan satu dengan yang lainnya. Setiap penyajian yang berbeda-beda tersebut nantinya akan mengalami perbedaan serta perubahan dalam sajian tafsir garapnya. 
Pemilihan gending dalam garap musikal film Setan Jawa sebagian menggunakan gending-gending karya lama. Hal ini selain digunakan untuk menghidupkan suasana film tersebut juga pemilihan gending juga disesuaikan konteks dalam adegan cerita.

\section{Kepustakaan}

Hastanto, Sri. 2009. Konsep Pathet Dalam Karawitan Jawa. Surakarta: ISI Press Surakarta.

Supanggah, Rahayu. 2009. Boyhèkan Karawitan II: Garap. Surakarta: ISI Pers Surakarta.

Sumarto, Dwi Priyo, 2003. “Kajian Garap Gendhing Kutut Manggung", Skripsi S-1 Surakarta: STSI Surakarta.

Widodo. 2016. “Gending Karawitan: Kajian Fungsi dan Garap Karawitan Gaya
Surakarta". Skripsi jurusan Karawitan Institut Seni Indonesia Surakarta.

Bukti Budaya Djarum Foundation. "Pertunjukan Kusus untuk Indonesia SETAN JAWA a silent movie with live gamelan orchestra".

Suraji. 1991. “Onang-onang Gending Kethuk 2 Kerep Minggah 4: Sebuah Tinjauan Tentang Garap, fungsi, serta struktur musikalnya". Laporan penelitian, STSI Surakarta.

\section{Daftar Narasumber}

1. Eko Widodo, Sri ( 34 tahun), seniman Karawitan (pengendhang), dan musisi film Setan Jawa.

2. Pambayun, Wahyu Thoyyib (26 tahun), seniman Karawitan (penggendèr), dan musisi film Setan Jawa. 